\title{
Synthesis of Some of Azo, Triazines and Schiff Bases Compounds from 4-Aminohippuric Acid
}

\author{
Mohammed A. Sheat \\ Chemistry Department / College of Science \\ University of Mosu \\ Zenab F. Saeed \\ Mohammed J. Mohammed \\ Veternary Medicine College \\ University of Mosul
}

Received

$\cdot 7 / 04 / 200 \wedge$
Accepted

$01 / 12$ / 2008

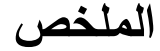

حضرت ثلاثة سلاسل جديدة من مشتقات استر 4-امينو حامض الهبيوريك، حيث

حضرت مركبات الازو (4a-f) ومركبات الازو الامينية (5a-e) من تفاعلات الإضافة

الالكتروفيلية لكلوريد- 4- دايازونيوم استر حامض الهبيوريك مع الفينولات والانيلين والامينات

الثانوية الاليفاتية، بينما حضرت قواعد شيف (6a-g) من تفاعلات التكثيف لاستر 4-امينو

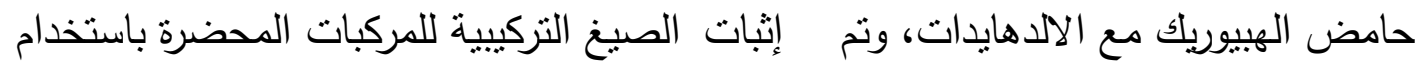
الطرائق الفيزياوية والطيفية.
\end{abstract}

\begin{abstract}
Three new series of 4-aminohippuric acid ester derivatives have been prepared. The azo (4a-f) and azoamino (5a-e) compounds were prepared from electrophilic addition reaction of 4-diazonium chloride hippuric acid ester with phenols, aniline and secondary aliphatic amines, while Schiff bases(6a-g) were prepared from the condensation of 4aminohippuric acid ester with aldehydes. The structural formula of the prepared compounds were confirmed by physical and spectral methods.
\end{abstract}




\section{Introduction}

Hippuric acid (aminoacid derivative) was used in the synthesis of azlactones or 5-oxazolones which are regarded as intermiediate compounds of high importance in the synthesis of $\alpha$-aminoacids and azlactones, also takes part in thyroxine synthesis [1]. Some of hippuric acid derivatives (acetylenic amines containing hippurate group) showed biological acivity as antibacterial agents [2].

The 4-aminohippuric acid derivative could behave as primary aromatic amines and react with nitous acid to form diazonium salt which have an important applications in organic synthesis such as the reaction with phenols and amines to yield the azo compounds [3]. The latter compounds have useful applications especially in dyes industry such as in dying of polyester fibers, thermoplastic polymers [4], in addition to wools, leathers, papaers and polyamides fibers [5]. While the reactions of diazonium salt with secondary aliphatic amines yield azoamino compounds (triazines) [6]. A number of triazines showed medical and biological activity [7] e.g. antibacterial activity [8], others showed antitumor and anti-leukemia activity [9].

Moreover, primary aromatic amines have been used in the synthesis of Schiff bases through condensation reactions with aldehydes and ketons [10]. Schiff bases could be used as starting materials in synthesis of heterocyclic compounds [11]. Besides, they showed pharmaceutical activity as analgesic and antipyretic [12], antibacterial [13] and diureic agents [14].

\section{Experimental}

Melting points were measured on an electrothermal 1A 9000 Digital-series apparatus and are uncorrected. I.R. spectra were recorded by Infrared Spectrophotometer FTIR-Tensor 27-Bruker as KBr disc. U.V. spectra were obtained from Shimadzu UV-Visible spectrophotometer UV-160 using absolute EtOH.

\section{Methods of Preparation} preparation of Sodium 4-Aminohippurate (1) [2]:

4-Aminohippuric acid (0.02 mole) was dissolved in a solution of sodium bicarbonate $(0.02$ mole $)$ in water $(15 \mathrm{ml})$. The solution was evaporated to dryness to obtain a white powder of sodium salt. The latter salt was found to have high melting point $\left(>300{ }^{\circ} \mathrm{C}\right)$ and readily soluble in water.

\section{Preparation of Benzyl-4-Aminohippurate (2) [2]:}

Benzyl chloride $(0.02$ mole, $2.53 \mathrm{~g})$ was added to a solution of sodium 4- aminohippurate (0.02 mole, $4.32 \mathrm{~g})$ in dimethyl sulfoxide (15 
$\mathrm{ml})$. The mixture was heated with stirring on a water bath at $\left(70-80^{\circ} \mathrm{C}\right)$ for 90 minutes with stirring. After cooling, cold water $(30 \mathrm{ml})$ was added with stirring till the oily product changed to solid precipitate. The precipitate was filtered, washed with cold water and dried, then recrystallized from ethanol to obtain a white powder of 58\% and m.p. $\left(113-115^{\circ} \mathrm{C}\right)$. The spectral data of compound (2) showed the following characteristic absorption bands:

$v_{\mathrm{C}=\mathrm{O}} 1741 \mathrm{~cm}^{-1}$ (s) (esteric), $v_{\mathrm{C}=\mathrm{O}} 1652 \mathrm{~cm}^{-1}$ (s) (amidic),

$\cup_{\mathrm{N}-\mathrm{H}} 3355 \mathrm{~cm}^{-1}(\mathrm{~b}), \quad \lambda_{\max }(\mathrm{EtOH}) 286 \mathrm{~nm}$

\section{Preparation of 4-Diazonium Chloride Benzyl hippurate (3) [15]}

A mixture of concentrated hydrochloric acid $(4 \mathrm{ml})$ and crushed ice (6 gm was cooled in ice-bath to $\left(0-5{ }^{\circ} \mathrm{C}\right)$, then benzyl-4-aminohippurate $(0.0028$ mole, $0.8 \mathrm{~g})$ was added gradually with stirring. After addition, the mixture was stirred for additional (10 minutes). A solution of sodium nitrite $(0.003$ mole, $0.21 \mathrm{~g})$ in $(2 \mathrm{ml})$ of cold water was added slowly. The colour of the solution was changed from white to yellow. The mixture was stired for (15minutes) and kept at $\left(0-5{ }^{\circ} \mathrm{C}\right)$, thus diazonium salt is ready to be used.

\section{Preparation of Azo Compounds (4a-f) [15]:}

The prepared diazonium salt solution was slowly added with stirring to a cooled aromatic amine $(0.0056$ mole) or to a cooled solution of phenol (0.0056 mole) in $(5 \mathrm{ml})$ of sodium hydroxide $(10 \%)$. A solid product was formed immediately. After the addition was completed, the mixture was stirred for (10 minutes). The precipitate was filtered, washed with water, dried and recrystallized from ethanol. The physical and spectral data of the azo compounds (4a-f) are listed in Table (1).

\section{Preparation of Triazines (5a-e) [6]:}

The prepared diazonium salt solution was added to a solution of secondary aliphatic amine $(0.003$ mole $)$ in $(5 \mathrm{ml})$ of potassium hydroxide (1.1 molar) with stirring for (10 minutes). The precipitate was filtered, washed with water, dried and recrystallized from ethanol. The physical and spectral data of the triazine compounds (5a-e) are listed in Table (1).

\section{Preparation of Schiff bases (6a-g)[16]:}

Aldehydes (0.005 mole) was added to a solution of benzyl 4aminohippurate $(0.005 \mathrm{~mole})$ in absolute ethanol $(15 \mathrm{ml})$. The mixture was refluxed for (6 hrs) and the solution was concentrated to half of it's volume. After cooling, the precipitate was filtered, washed with cold ethanol, dried and recrystallized from ethanol. The physical and spectral data of the Schiff bases (6a-g) are listed in Table (1). 

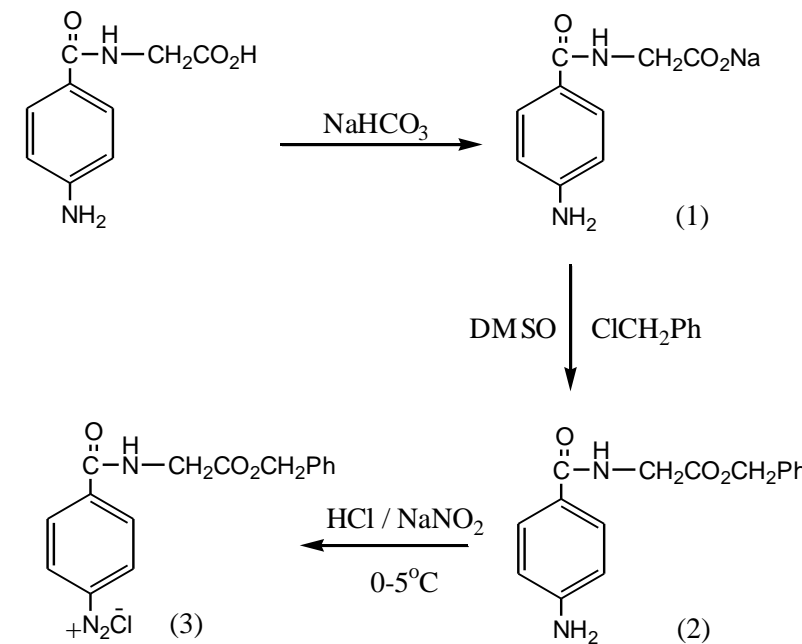

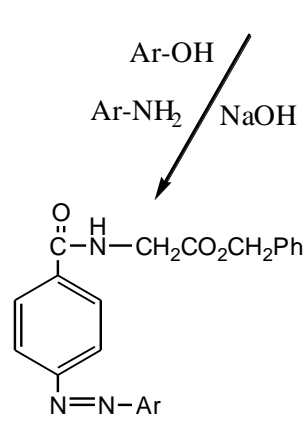

(4a-f)
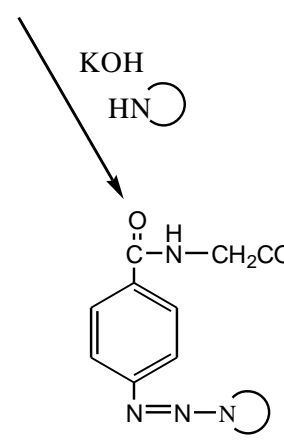

$(5 a-e)$
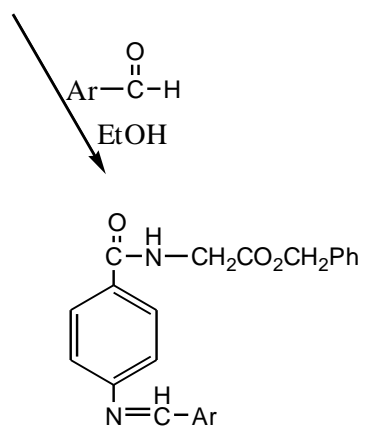

(6a-g)

Scheme (1)

\begin{tabular}{|c|c|c|c|c|c|}
\hline Compd. No. & Ar & Compd. No. & $-\mathrm{N}$ & Compd. No. & $=\stackrel{\mathrm{H}}{\mathrm{C}}-\mathrm{Ar}$ \\
\hline $4 a$ & & $5 a$ & & $6 a$ & \\
\hline $4 b$ & & $5 b$ & & $6 \mathrm{~b}$ & \\
\hline $4 c$ & & $5 c$ & & $6 c$ & $=\stackrel{H}{\mathrm{C}}-$ \\
\hline $4 d$ & & $5 \mathrm{~d}$ & & & $=\stackrel{\mathrm{H}}{\mathrm{C}}$ \\
\hline $4 \mathrm{e}$ & & $5 \mathrm{e}$ & & $6 \mathrm{e}$ & $={ }^{\mathrm{H}}-$ \\
\hline $4 \mathrm{f}$ & & & & $6 f$ & \\
\hline & & & & $6 \mathrm{~g}$ & $=\stackrel{\mathrm{H}}{\mathrm{C}}-\stackrel{\mathrm{H}}{\mathrm{C}}=\mathrm{CH}_{2}$ \\
\hline
\end{tabular}




\section{Results and Discussion}

4-Aminohippuric acid was reacted with sodium bicarbonate to give sodium salt (1) [2] which allowed to react with benzyl chloride to obtain benzyl-4-aminohippurate (2) [2]. Similar salts such as potassium amino benzoate were found to react with propargyl bromide [17a,b] and with p. nitrobenzyl choloride [18] to yield ester compounds respectively.

The diazotization of compound (2) with nitrous acid at $\left(0-5{ }^{\circ} \mathrm{C}\right)$ afforded diazonium salt (3). This salt couples readily with phenols or amines by simple aromatic electrophillic substitution reaction to form azo compounds (4a-f) [19]. But the reactions of diazonium salt with secondary aliphatic amines gave azoamino compounds (5a-e) through the following electrophilic substitution mechanism [6] Scheme (2).

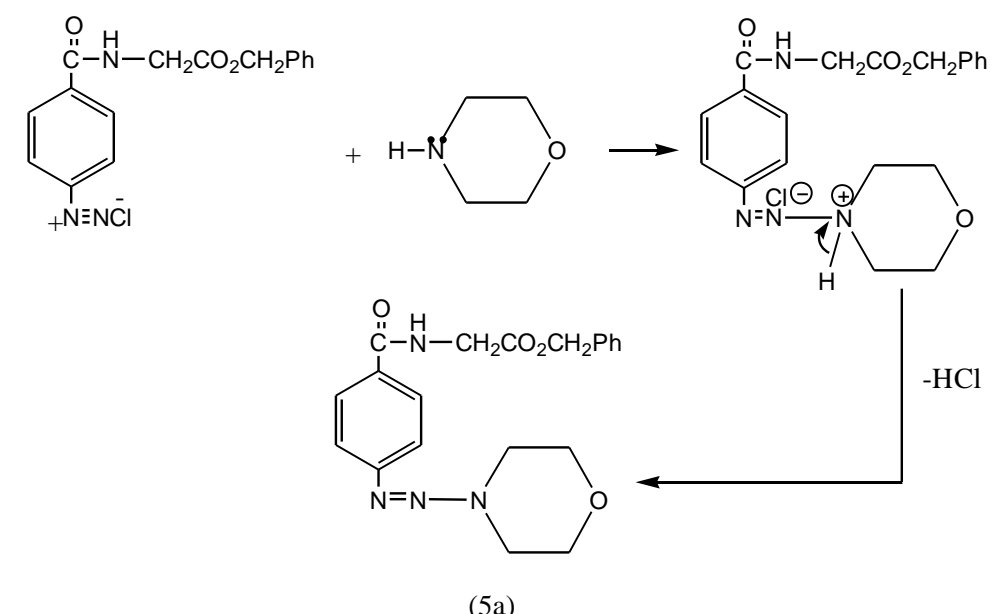

Scheme (2)

The formation of Schiff bases (6a-g) was carried out from the reaction of amino group of 4-aminohippuric acid ester with aldehydes through neucleophilc addition tetrahydral mechanism [20] Scheme (3).

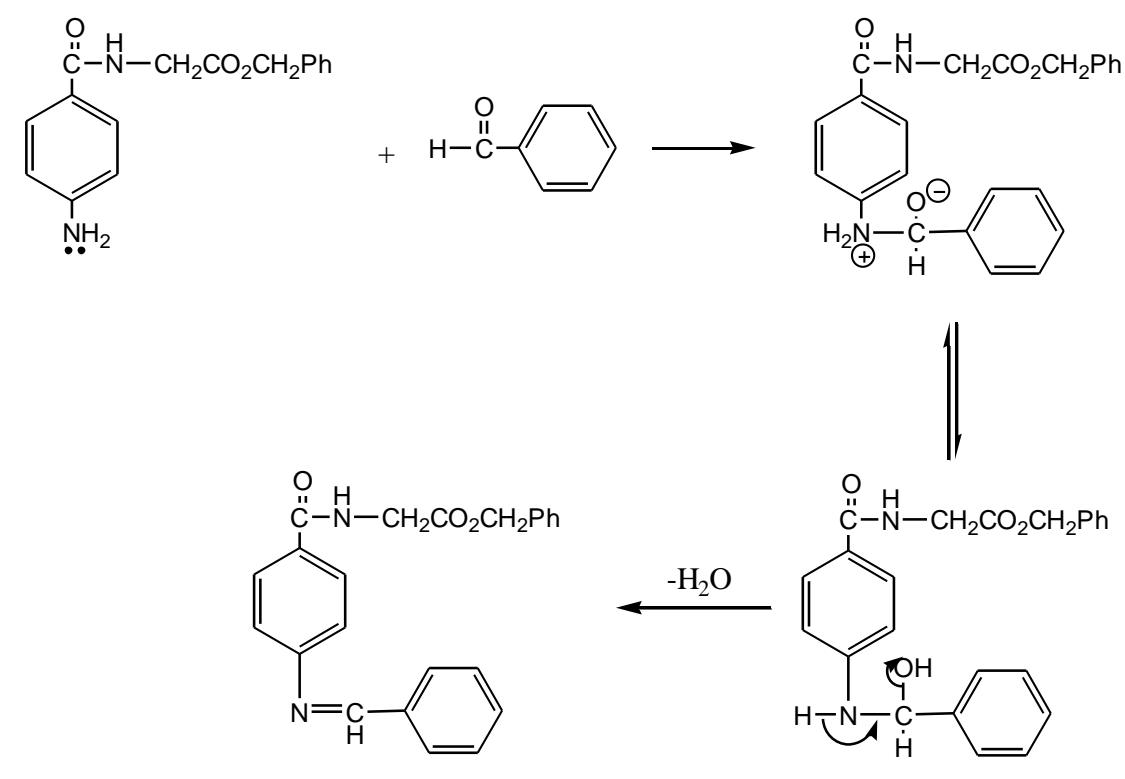

Scheme (3) 
The synthesized 4-aminohippuric acid ester derivatives $(4,5,6)$ have been investigated according to their physical and spectral data (I.R. and U.V.) as shown in Table (1).

The I.R. spectra of the synthesized compounds $(4,5,6)$ showed two strong absorption bands at the region (1719-1745) $\mathrm{cm}^{-1}$ and (1630$1649) \mathrm{cm}^{-1}$ for the stretching vibration of the esteric and amidic carbonyl groups respectively. A medium band at the region(1571-1597) $\mathrm{cm}^{-1}$ was appeared due to the stretching vibration of the azo group $\left(\mathrm{v}_{\mathrm{N}=\mathrm{N}}\right)$ in the compounds $(4,5)$. Similar medium band at the region $(1605-1615) \mathrm{cm}^{-1}$ due to the stretching vibration of the carbon-nitrogen double bond $\left(v_{\mathrm{C}=\mathrm{N}}\right)$ in the compounds (6). The decreasing in the stretching vibration values in the azo group $(\mathrm{N}=\mathrm{N})$ and imine group $(\mathrm{C}=\mathrm{N})$ in the compounds $(4,5,6)$ was expected due the appearance of high conjugation effect in these compounds [21].

The U.V. spectra of the synthesized compounds $(4,5,6)$ showed the bands for the maximum absorptions at $\left(\lambda_{\max } 306-364 \mathrm{~nm}\right)$. These $\lambda_{\max }$ values supported the expected structures of the compounds $(4,5,6)$ because the high conjugation will causes a high bathochromic shift in the $\mathrm{n} \rightarrow \pi^{*}$ transition especially in the compounds(4a-f) [21].

Table (1): Physical and spectral data of the synthesized compounds $(4,5,6)$

\begin{tabular}{|c|c|c|c|c|c|c|c|c|}
\hline \multirow{2}{*}{ 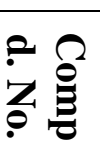 } & \multirow{2}{*}{$\begin{array}{c}\text { Yield } \\
\%\end{array}$} & \multirow[b]{2}{*}{ m.p. ${ }^{\circ} \mathrm{C}$} & \multicolumn{5}{|c|}{ I.R. $\mathrm{cm}^{-1}(\mathrm{KBr})$} & \multirow{2}{*}{$\begin{array}{c}\text { U.V. } \\
\lambda_{\max }(\mathrm{nm}) \\
\text { EtOH }\end{array}$} \\
\hline & & & $\begin{array}{c}U_{\mathrm{C}}=0 \\
\text { esteric }\end{array}$ & $\begin{array}{c}U_{\mathrm{C}=\mathrm{O}} \\
\text { amidic }\end{array}$ & $\mathrm{U}_{\mathrm{N}=\mathrm{N}}$ & $U_{\mathrm{C}=\mathrm{N}}$ & $\begin{array}{l}v_{N} H \\
\text { (br) }\end{array}$ & \\
\hline $4 a$ & 65 & $246-248$ & 1733 & 1649 & 1571 & - & 3388 & 332 \\
\hline $4_{b}$ & 30 & $190-192$ & 1729 & 1638 & 1574 & - & 3395 & 334 \\
\hline $4_{c}$ & 35 & $>300$ decomp. & 1720 & 1637 & 1578 & - & 3315 & 354 \\
\hline $4_{d}$ & 40 & $>300$ decomp. & 1736 & 1630 & 1571 & - & 3386 & 338 \\
\hline $44_{e}$ & 80 & 184-186 & 1720 & 1635 & 1590 & - & 3331 & 364 \\
\hline $4_{f}$ & 50 & $225-227$ & 1737 & 1642 & 1597 & - & 3387 & 352 \\
\hline $5 \mathrm{a}$ & 52 & $163-165$ & 1728 & 1636 & 1584 & - & 3325 & 312 \\
\hline $5 \mathrm{~b}$ & 60 & 117-119 & 1730 & 1632 & 1588 & - & 3353 & 314 \\
\hline $5 \mathrm{c}$ & 46 & 131-134 & 1733 & 1630 & 1580 & - & 3320 & 306 \\
\hline $5 \mathrm{~d}$ & 55 & $156-158$ & 1730 & 1634 & 1591 & - & 3382 & 320 \\
\hline 5 e & 65 & $215-217$ & 1734 & 1650 & 1597 & - & 3320 & 336 \\
\hline 6 & 83 & $165-167$ & 1745 & 1644 & - & 1605 & 3319 & 306 \\
\hline $6_{b}$ & 50 & 169-171 & 1719 & 1637 & - & 1609 & 3293 & 310 \\
\hline $6_{c}$ & 30 & 137-139 & 1724 & 1637 & - & 1615 & 3311 & 306 \\
\hline $6_{d}$ & 25 & 188-190 & 1734 & 1641 & - & 1608 & 3270 & 312 \\
\hline 6 & 40 & $142-144$ & 1741 & 1632 & - & 1612 & 3347 & 320 \\
\hline $6_{f}$ & 45 & 213-215 & 1744 & 1630 & - & 1610 & 3367 & 318 \\
\hline $6 g$ & 35 & $162-165$ & 1720 & 1638 & - & 1603 & 3305 & 306 \\
\hline
\end{tabular}




\section{References}

1) I. L. Finar, "Organic Chemistry", Longman, London, $5^{\text {th }}$ ed., II, 644, 654, 1975.

2) M. A. Sheat, and Z. F. Saeed, Nat. J. of Chem., 21, 53, 2006.

3) R. T. Morrison and R. N. Boyed, "Organic Chemistry", Allyn and Bacon Inc., Toronto, $5^{\text {th }}$ ed., 976, 1987.

4) R. Hamprecht and M. Hoppe, Ger Offen, Pattent, (1988); Chem. Abst., 112: 218762, 1990.

5) A. Kujawski, L. Szuster, A. Gawlowski, J. Jabloski and M. Olma, Pol., Pattent (1989); Chem. Abst., 12: 218760a, 1990.

6) N. I. Foster, N. D. Heindel, H.D. Burns and W. Multr, Synthesis, $572,1980$.

7) A. Kreutzberger and J. Stratmann, J. Heterocyclic Chem., 17 (7), 1505, 1980; Chem. Abst., 94: 121419t, 1980.

8) M. Bineshmarvasti, M. Sharifzadeh, A.R. Jalilian, K.S. Taninejad and A. Shafiee, Daru, 11, 2, 2003, (http://www.tums.ac.ir/daru/ Daru2/20 2003/Dr/20 Bineshmarvasi.pdf).

9) J. Liu, B. Zhang and J. Sun, (Inst. Ivled Pharm., Sci., Tianjin, Peop. Rep. China Yiyao Gongye, 18(9), 395-398 (Ch), 1987; Chem. Abst., 109: 37559j, 1988.

10) F. A. Carey, "Organic Chemistry", MeGraw-Hill Companies Inc., New York, $3^{\text {rd }}$., 700, 1996.

11) J. L. Riebsomer, J. Org. Chem., 15, 237, 1950; Chem. Abst., 44: 4477c, 1950.

12) Negrevergne, Georges. Ger Offen, 2, 303, 521, 1973; Chem. Abst., 80: 3232, 1974.

13) F. D. Karia and P. H. Parasania, Asian J. Chem., 11(3), 991, 1999; Chem. Abst. 131 (17): 228516g, 1999.

14) "British Pharmacopeia on Cd-Rom", $3^{\text {rd }}$. System Simulation Ltd., The Stationer Office, London, 2000, p. 181, 306, (http://www. Pharmacopoeia-co.UK). 
15) W. W. Linstromberg and H. E. Baumgarten, "Organic Experiments", D. C. Health and Company, Toronto, $5^{\text {th }}$ ed., 125, 257, 1983.

16) A. W. Baker and A. T. Shulgin, J. Am. Chem. Soc., 81, 1524, 1959.

17) a. H. Y. Hussin, "Synthesis of Acetylenic Derivatives of p. Aminobenzoic Acid with the Expected Biological Activity", University of Mosul, 1999; M.Sc. Thesis.

b. S. S. Wang; B. F. Gisin; D. P. Winter and R. Makofske, J.Org. Chem., 1977; 42(8), 1286.

18) N. D. Cheronis and J. B. Entrikin, "Identification of Organic compounds", John Wily and Sons, Inc, New York, London, Sydeny, 1963.

ترجمة : موفق شندالة، روعة غياث الدين ونزار الجبور، مديرية دار الكتب للطباعة والنشر،

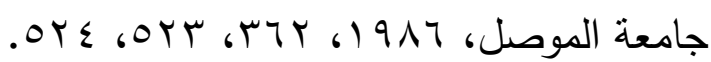

19) N. K. Vishnoi, "Advanced Practical Organic Chemistry", Vikas Publishing House PVILTD, 341, 1982.

20) W. H. Brown, "Introduction to Organic Chemistry", Saunday College Publishing, New York, 401, 1997.

21) V. M. Parikh, "Absorption Spectroscopy of Organic Molecules". ترجمة : عبد الحسين شربة، جاسم الراوي ومحمد العراقي، مديرية مطبعة الجامعة، جامعة

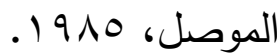

